\title{
The effect of covering material on the yield, quality and chemical composition of greenhouse-grown tomato fruit
}

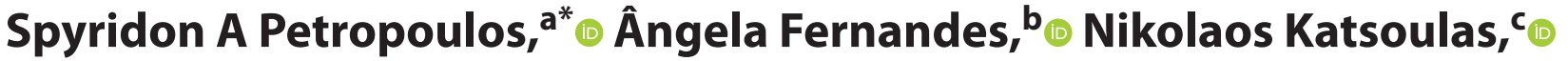 \\ Lillian Barros ${ }^{\mathbf{b}} \odot$ and Isabel CFR Ferreira ${ }^{b^{*}} \odot$
}

\begin{abstract}
BACKGROUND: During the last few decades, greenhouse technology for horticultural crops has focused on retaining optimum conditions within the greenhouse environment that could allow for a compromise between maximum yields and minimum production costs. The aim of this study was to evaluate the effect of three greenhouse covering materials and five harvesting dates on the yield and quality parameters of hydroponically produced tomato fruit, as well as on energy consumption.

RESULTS: Plants had a higher growth rate at early stages for S-PE cover material, while differences were minimized at later stages. Tocopherol content was the highest for ID-PE material and harvesting later than 170 days after transplanting (DAT), while sugar content (fructose and glucose) was the highest for S-PE material and 157 DAT. Organic acid content was the highest at early harvestings, especially for 7-PE and S-PE cover materials, while it exhibited decreasing trends at later harvesting dates. Antioxidant properties showed a varied response to cover materials and harvesting dates, while $\beta$-carotene, carotenoids and chlorophylls were the highest for 7-PE material.
\end{abstract}

CONCLUSIONS: The results showed that both cover materials and harvesting date may affect significantly tomato fruit quality, especially sugar and organic acid contents which are associated with fruit taste, as well as tocopherols which contribute to antioxidant properties and pigments that are associated with fruit ripening and earliness of marketable maturity.

(c) 2018 Society of Chemical Industry

Keywords: antioxidant activity; carotenoids; cover materials; double-layer films; Solanum lycopersicum L.; tomato fruit

\section{INTRODUCTION}

Greenhouse production of horticultural crops is associated with high production costs, especially in the case of out-of-season production and heating systems where conventional fuels are used. To overcome this problem, various new technologies have been introduced during the last few decades for the production of new greenhouse covering materials that could allow for more efficient climate control within the greenhouse environment, ${ }^{1,2}$ with special interest in optical properties and thermal performance of these materials. ${ }^{3}$ Most of these technologies focus on producing greenhouse claddings with light-manipulating properties, such as photo-selective films, shading nets, UV-blocking films and double-layer films among others, that could minimize energy losses and increase yield without disproportional increase in energy inputs. ${ }^{4-6}$ However, reduction in energy consumption from covering materials is usually associated with reduced light availability to plants, with reduced yields and effects on the end product quality being expected., 2,7 Moreover, the varied effects of cover materials on light intensity and quality necessitate the proper selection of covers depending on cultivated species, cultivation period and product quality standards. ${ }^{8-10}$

Several studies have reported the beneficial effects of photo-selective films on visual quality of tomato fruit, mostly in terms of marketability standards such as fruit texture and colour, as well as regarding the low incidents of fruit injuries due to sun scalding. ${ }^{11-13}$ Moreover, Ilić et al. ${ }^{6}$ have reported a significant effect of covering materials on carotenoid content in tomato fruit due to temperature and light conditions that induce the biosynthesis of these pigments. Double-layer polyethylene (PE) films exhibited similar marketable fruit yield and energy consumption, whereas although double-layer polycarbonate films were more efficient in terms of energy use efficiency, fruit quality was slightly worse compared to PE films. ${ }^{14}$ In addition, according to Jarquín-Enríquez et al., ${ }^{15}$ double-layer PE films resulted in higher

\footnotetext{
Correspondence to: SA Petropoulos, School of Agricultural Sciences, University of Thessaly, Fytokou Street, 38446 N. Ionia, Magnissia, Greece. E-mail: spetropoulos@uth.gr; or ICFR Ferreira, Centro de Investigação de Montanha (CIMO), Instituto Politécnico de Bragança, Campus de Santa Apolónia, 5300-253 Bragança, Portugal. E-mail: iferreira@ipb.pt

a Department of Agriculture, Crop Production and Rural Environment, Laboratory of Vegetable Production, University of Thessaly, Ionia, Greece

b Biologia e Biotecnologia, Centro de Investigação de Montanha (CIMO), Instituto Politécnico de Bragança, Bragança, Portugal

c Department of Agriculture, Crop Production and Rural Environment, Laboratory of Agricultural Constructions and Environmental Control, University of Thessaly, Ionia, Greece
} 
lycopene content and better fruit colour than flat glass covering coated with $\mathrm{CaCO}_{3}$ due to lower amounts of accumulated light in the latter covering material. Growing conditions within a greenhouse environment may also affect bioactive compound content in tomato fruit, especially irradiance and temperature levels which have a pivotal role in lycopene and $\beta$-carotene biosynthesis, and phenolic compounds content, such as caffeic acid and rutin. ${ }^{16}$

During the last few decades, greenhouse technology for horticultural crops has focused on optimizing environmental conditions within the greenhouse having also in mind to combine maximum yields with minimum production costs. Several studies have reported the effect of covering materials on yield and basic quality parameters of tomato and other fruit vegetables, giving emphasis on sugar and carotenoid contents, titratable acidity, aroma profile and visual appearance. ${ }^{17-20}$ The aim of the study reported here was to evaluate the effect of covering materials and harvesting dates on chemical composition and antioxidant properties of tomato fruit, while at the same time measurements regarding total energy consumption and yield were also carried out.

\section{MATERIALS AND METHODS}

\section{Greenhouse facilities and growing conditions}

Experiments were conducted during the growing period of December 2016-June 2017 in three identical arched roof greenhouses, north-south oriented, located at the University of Thessaly experimental farm (latitude $39^{\circ} 22^{\prime} \mathrm{N}$, longitude $22^{\circ} 44^{\prime} \mathrm{E}$, altitude $85 \mathrm{~m}$ ). Each greenhouse had the following constructional characteristics: eaves height: $2.9 \mathrm{~m}$; ridge height: $4.1 \mathrm{~m}$; total width: $8 \mathrm{~m}$; total length: $20 \mathrm{~m}$; ground area: $160 \mathrm{~m}^{2}$; volume: $524 \mathrm{~m}^{3}$. Moreover, ventilation was implemented through automatically controlled vents (Argos Electronics, Athens, Greece): two continuous side roll-up windows (total opening area of $27 \mathrm{~m}^{2}$ ) and a flap roof window (total opening area of $18 \mathrm{~m}^{2}$ ). Heating was provided via aboveground PVC pipes and a fan coil located at a height of $2.6 \mathrm{~m}$. Each greenhouse floor was covered with a white on black plastic sheet. Temperature was automatically controlled by opening vents (at $>22^{\circ} \mathrm{C}$ ) and using a heating system (at $<14^{\circ} \mathrm{C}$ during the night and $<18^{\circ} \mathrm{C}$ during the day).

Each greenhouse was covered with a different covering material as follows: (i) a conventional single three-layer polyethylene (PE) film with normal diffusion fraction and $18 \%$ transmission to infrared radiation (S-PE); (ii) two PE films inflated (ID-PE), consisting of an external three-layer PE film with low diffusion fraction and $50 \%$ transmission to infrared radiation and an internal three-layer PE film with low diffusion fraction and $18 \%$ transmission to infrared radiation; and (iii) a seven-layer PE film that formed two three-layer films, as in case (ii), splinted by an empty layer to form two independent films produced and placed in the greenhouse as one film which then was inflated (7-PE). All PE films had $180 \mu \mathrm{m}$ thickness and $90 \%$ transmission to solar radiation and were supplied by Plastika Kritis SA (Heraclion, Crete, Greece).

\section{Plant materials and measurements}

Tomato plants (Solanum lycopersicum, cv. Elpida) were transplanted on 12 May 2016 at the stage of $15-20 \mathrm{~cm}$ and grown hydroponically in rockwool bags at a density of 2.4 plants $\mathrm{m}^{-2}$ (320 plants in total for each greenhouse). Plants were irrigated via an automatically controlled drip irrigation system, water needs were estimated based on crop transpiration and set points for electrical conductivity and $\mathrm{pH}$ were at $2.1 \mathrm{dS} \mathrm{m}^{-1}$ and 5.6, respectively. Nutrient solution composition was common for all the greenhouses, containing $3.0 \mathrm{mmol} \mathrm{L}^{-1} \mathrm{Ca}^{2+}, 8.0 \mathrm{mmol} \mathrm{L}^{-1}$ $\mathrm{K}^{+}, 1.60 \mathrm{mmol} \mathrm{L}^{-1} \mathrm{Mg}^{2+}, 1.80 \mathrm{mmol} \mathrm{L}^{-1} \mathrm{NH}_{4}^{+}, 13.2 \mathrm{mmol} \mathrm{L}{ }^{-1}$ $\mathrm{NO}_{3}{ }^{-}, 1.3 \mathrm{mmol} \mathrm{L}^{-1} \mathrm{H}_{2} \mathrm{PO}_{4}^{-}, 2.25 \mathrm{mmol} \mathrm{L}^{-1} \mathrm{SO}_{4}{ }^{2-}, 24 \mu \mathrm{mol} \mathrm{L}{ }^{-1} \mathrm{~B}$, $15 \mu \mathrm{mol} \mathrm{L}^{-1} \mathrm{Fe}, 10 \mu \mathrm{mol} \mathrm{L}^{-1} \mathrm{Mn}, 5 \mu \mathrm{mol} \mathrm{L}^{-1} \mathrm{Zn}, 0.8 \mu \mathrm{mol} \mathrm{L}^{-1} \mathrm{Cu}$ and $0.5 \mu \mathrm{mol} \mathrm{L}^{-1}$ Mo. Flower pollination was enabled by installing a beehive of bumblebees Bombus terrestris (L.) in each greenhouse.

Plants were trained to a single stem trellising system, with twines attached to a top wire above each row of plants at $2.4 \mathrm{~m}$ height. Plants were topped when they reached the top wire, while fruit clusters were thinned to five fruits per cluster throughout the growing period in order to retain fruit size uniformity. Fruits were harvested five times on 21 April, 11 May, 24 May, 7 June and 21 June 2017 (137, 157, 170, 184 and 198 days after transplanting (DAT), respectively) and when they reached the fully red/ ripe maturity stage, from 18 selected plants from each greenhouse (three groups of six plants for each greenhouse). After harvest, fruit fresh and dry weight was estimated, while batch samples from fresh fruit were chopped in pieces and put in air-sealed plastic bags at deep-freezing conditions $\left(-80^{\circ} \mathrm{C}\right)$ until further analysis. Total yield was estimated for the complete number of plants for each greenhouse, including the yield of plants selected for growth and chemical composition measurements.

\section{Chemical composition analyses \\ Nutritional value}

Fruit samples were analysed in terms of macronutrients (moisture, proteins, fat, carbohydrates and ash), according to the AOAC procedures. $^{21}$ Total carbohydrates were calculated by difference and the energetic value was calculated as follows: energy $(\mathrm{kcal})=4 \times\left(g_{\text {protein }}+g_{\text {carbohydrate }}\right)+9 \times\left(g_{\text {fat }}\right)$.

\section{Tocopherols}

Tocopherols were determined following a procedure previously described, ${ }^{22}$ using a high-performance liquid chromatography (HPLC) system (Smartline System 1000, Knauer, Berlin, Germany) coupled to a fluorescence detector (FP-2020, Jasco, Easton, USA). The results were recorded and processed using Clarity 2.4 software (DataApex, Prague, Czech Republic).

\section{Free sugars}

Free sugars were determined by HPLC coupled to a refractive index detector (Smartline System 1000), using the internal standard melezitose (Sigma-Aldrich, St Louis, MO, USA) according to the method previously described by Barros et al. ${ }^{22}$ The results were recorded and processed using Clarity 2.4 software.

\section{Organic acids}

Organic acids were identified and quantified by ultra-fast liquid chromatography (Shimadzu 20A series, Shimadzu Corporation, Kyoto, Japan) coupled to a diode-array detector operating in the conditions described by Barros et al. ${ }^{23}$ The results were recorded and processed using LabSolutions Multi LC-PDA software (Shimadzu Corporation, Kyoto, Japan).

\section{Fatty acids}

Fatty acids were identified using a gas chromatograph (DANI1000, Contone, Switzerland) provided with a split/splitless injector and a flame ionization detector (at $260^{\circ} \mathrm{C}$ ) operating in the conditions 
described by Barros et $a l^{22}$ The results were recorded and processed using CSW 1.7 software (DataApex).

\section{Antioxidant activity}

Antioxidant activity and bioactive compounds were assessed according to methods previously reported by Barros et al. ${ }^{22}$ Methanol/water $(80: 20, \mathrm{v} / \mathrm{v})$ extracts were obtained from lyophilized material. Each sample $(1 \mathrm{~g})$ was extracted twice by stirring $\left(25^{\circ} \mathrm{C}\right.$ at $\left.150 \mathrm{rpm}\right)$ with $30 \mathrm{~mL}$ of methanol/water (80:20, $\mathrm{v} / \mathrm{v}$ ) for $1 \mathrm{~h}$ and subsequently filtered through a Whatman No. 4 paper. The combined methanol/water extracts were evaporated at $40^{\circ} \mathrm{C}$ using a rotary evaporator (Büchi R-210, Flawil, Switzerland) to remove the methanol and further frozen and lyophilized. The extracts were redissolved in methanol/water $(80: 20, v / v)$ at a final concentration of $50 \mathrm{mg} \mathrm{mL}^{-1}$ and further diluted to various concentrations to be submitted to in vitro assays.

The antioxidant activity was measured using four assays, namely 2,2-diphenyl-1-picrylhydrazyl (DPPH) radical-scavenging activity, reducing power, inhibition of $\beta$-carotene bleaching and lipid peroxidation inhibition measured by the thiobarbituric acid reactive substances reaction (TBARS) as previously described. ${ }^{22}$ The results were expressed in $\mathrm{EC}_{50}$ values (sample concentration providing $50 \%$ of antioxidant activity or 0.5 of absorbance in the reducing power assay) for antioxidant activity and Trolox was used as a positive control.

\section{Pigments}

The contents of carotenoids and chlorophylls were determined using a procedure previously described by Nagata and Yamashita. ${ }^{24}$ The absorbance of extracts was measured at 453, 505,645 and $663 \mathrm{~nm}$ and the contents of carotenoids ( $\beta$-carotene and lycopene) and chlorophyll a and b were calculated according to the following equations, and further expressed in $\mathrm{mg} / 100 \mathrm{~g}$ of fresh weight: $\beta$-carotene $(\mathrm{mg} / 100 \mathrm{~mL})=0.216 \times A_{663}-$ $1.220 \times A_{645}-0.304 \times A_{505}+0.452 \times A_{453}$; lycopene $(\mathrm{mg} / 100 \mathrm{~mL})$ $=-0.0458 \times A_{663}+0.204 \times A_{645}-0.304 \times A_{505}+0.452 \times A_{453}$; chlorophyll a $(\mathrm{mg} / 100 \mathrm{~mL})=0.999 \times A_{663}-0.0989 \times A_{645}$; chlorophyll b $(\mathrm{mg} / 100 \mathrm{~mL})=-0.328 \times A_{663}+1.77 \times A_{645}$.

\section{Statistical analysis}

The experiment was laid out according to randomized complete blocks design for each greenhouse $(n=6)$ with three replicates for harvesting date treatment. For chemical composition, three samples were analysed for each treatment (harvest date and cover material), while all the assays were carried out in triplicate. Results were expressed as mean values and standard deviations (SD), and analysed using one-way analysis of variance (ANOVA) followed by Tukey's HSD test with $P=0.05$. This analysis was carried out using Statgraphics 5.1.plus (Statpoint Technologies Inc., VA, USA).

\section{RESULTS}

\section{Growth parameters and total yield}

Plant height during the experimental period is presented in Fig. 1(A). Height was greater for plants grown in the greenhouse covered with S-PE material during the early growth stages (until 24 February 2017). However, later on differences were not statistically different and plants had a uniform development up to the maximum height of the horizontal supporting wire. Mean fruit weight was approximately $250 \mathrm{~g}$ and was not significantly
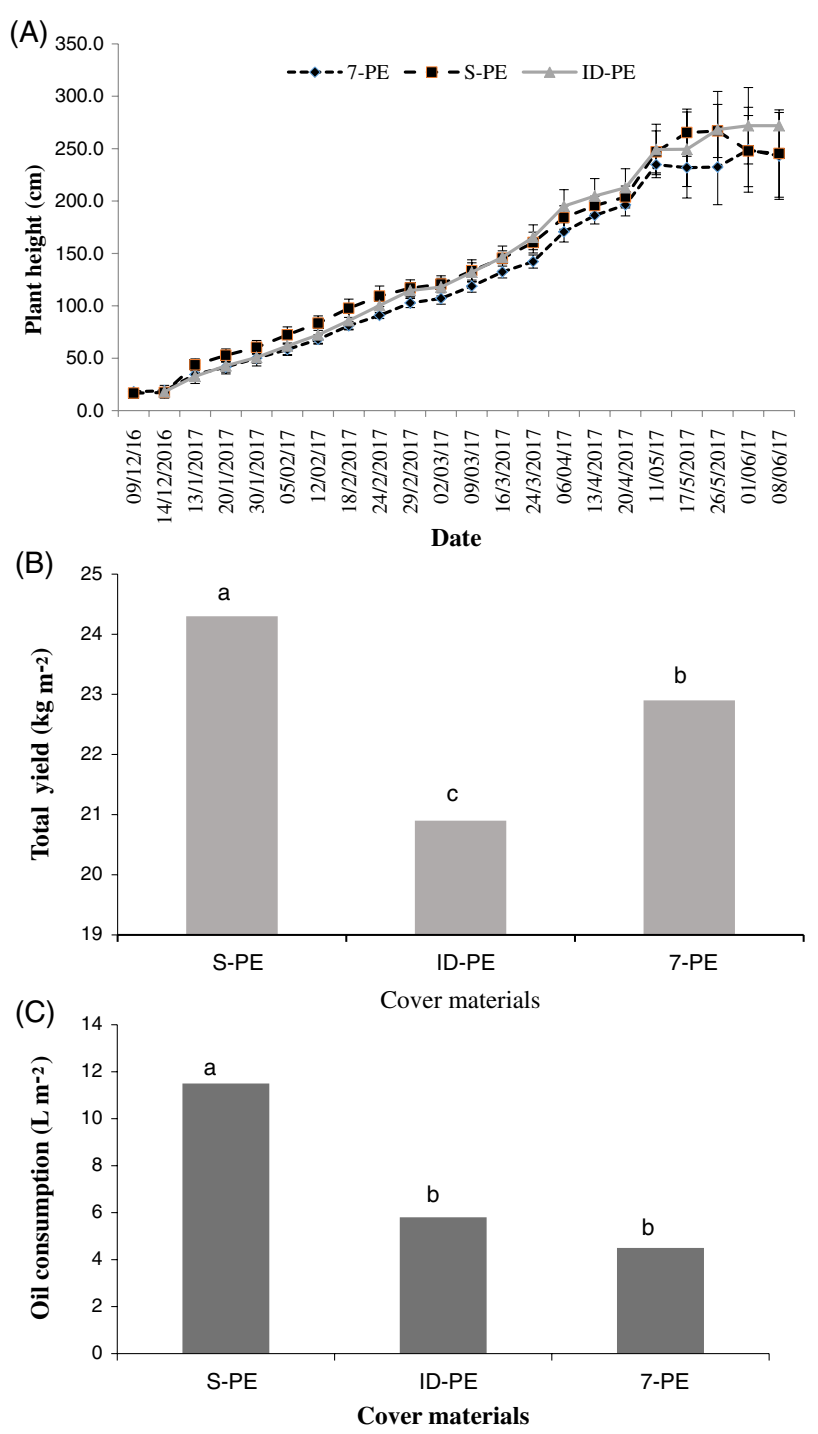

Figure 1. (A) Plant height of tomato plants during the experimental period. (B) Total fruit yield in relation to cover materials. (C) Energy consumption in relation to cover materials. 7-PE, 7-layer low density polyethylene (PE) film; $\mathrm{S}-\mathrm{PE}$, single three-layer PE film; ID-PE, double inflated three-layer PE film.

affected by either cover material or harvesting date (data not shown), while the number of fruit was kept constant to 5 fruits truss $^{-1}$ for all the plants in order to have comparable results of total yield. Moreover, total yield showed significant differences among the studied cover materials, with S-PE having the highest yield $\left(24.3 \mathrm{~kg} \mathrm{~m}^{-2}\right)$, comparing to 7-PE and ID-PE materials (20.9 and $22.9 \mathrm{~kg} \mathrm{~m}^{-2}$, respectively) (Fig. 1(B)).

Apart from total yield, energy consumption (heating cost) differences and hence production cost between the studied cover materials were observed. Therefore, although S-PE material had the highest yield, it also had the highest fuel consumption $(11.5 \mathrm{~L}$ of oil $\mathrm{m}^{-2}$ ) compared to 7-PE (4.5 L of oil $\mathrm{m}^{-2}$ ) and ID-PE (5.8 L of oil $\mathrm{m}^{-2}$ ), which increased the production cost and eliminated any benefits from yield increases (Fig. 1(C)).

\section{Chemical composition}

Nutritional value of tomato fruit in relation to cover materials and harvesting date is presented in Table 1. Water content was affected only by harvesting date and showed a decreasing trend 


\begin{tabular}{|c|c|c|c|c|c|c|c|}
\hline Cover material (C) & DAT (T) & Moisture & Fat & Proteins & Ash & Carbohydrates & Energy \\
\hline \multirow[t]{5}{*}{ 7-PE } & 137 & $950 \pm 3 a b$ & $0.231 \pm 0.005 \mathrm{~m}$ & $5.59 \pm 0.01 c$ & $8.72 \pm 0.05 b c$ & $35.77 \pm 0.041$ & $167.5 \pm 0.2 \mathrm{k}$ \\
\hline & 157 & $944 \pm 2 b c$ & $0.73 \pm 0.01 i$ & $6.24 \pm 0.04 a$ & $8.0 \pm 0.2 e$ & $41.3 \pm 0.2 \mathrm{~g}$ & $196.6 \pm 0.6 f$ \\
\hline & 170 & $948 \pm 4 b$ & $1.04 \pm 0.01 c$ & $4.4 \pm 0.2 f$ & $8.3 \pm 0.2 d$ & $38.78 \pm 0.05 i$ & $181.9 \pm 0.5 \mathrm{i}$ \\
\hline & 184 & $944 \pm 3 b c$ & $0.94 \pm 0.01 e$ & $5.17 \pm 0.03 d$ & $6.0 \pm 0.2 h$ & $43.5 \pm 0.2 d$ & $203.2 \pm 0.4 d$ \\
\hline & 198 & $944 \pm 2 b c$ & $1.28 \pm 0.02 a$ & $6.0 \pm 0.1 b$ & $7.10 \pm 0.08 f$ & $41.73 \pm 0.03 f$ & $202.3 \pm 0.3 d$ \\
\hline \multirow[t]{5}{*}{ S-PE } & 137 & $954 \pm 4 a$ & $0.270 \pm 0.0011$ & $4.45 \pm 0.08 f$ & $6.5 \pm 0.2 \mathrm{~g}$ & $34.4 \pm 0.2 m$ & $157.7 \pm 0.51$ \\
\hline & 157 & $940 \pm 3 c$ & $0.93 \pm 0.02 \mathrm{e}$ & $5.6 \pm 0.5 c$ & $9.9 \pm 0.1 a$ & $43.9 \pm 0.4 c$ & $206.4 \pm 0.2 c$ \\
\hline & 170 & $944 \pm 1 b c$ & $0.70 \pm 0.01 j$ & $4.4 \pm 0.2 f$ & $7.2 \pm 0.3 f$ & $43.5 \pm 0.3 d$ & $197.9 \pm 0.9 e$ \\
\hline & 184 & $948 \pm 5 a b$ & $1.00 \pm 0.01 d$ & $5.11 \pm 0.02 \mathrm{de}$ & $6.6 \pm 0.1 \mathrm{~g}$ & $39.57 \pm 0.04 \mathrm{~h}$ & $187.7 \pm 0.3 \mathrm{~h}$ \\
\hline & 198 & $943 \pm 3 b c$ & $0.846 \pm 0.006 f$ & $6.0 \pm 0.1 b$ & $7.3 \pm 0.1 f$ & $42.70 \pm 0.01 \mathrm{e}$ & $202.3 \pm 0.4 d$ \\
\hline \multirow[t]{5}{*}{ ID-PE } & 137 & $948 \pm 4 a b$ & $0.32 \pm 0.01 \mathrm{k}$ & $5.50 \pm 0.04 c$ & $8.94 \pm 0.07 b$ & $37.42 \pm 0.07 j$ & $174.6 \pm 0.2 \mathrm{j}$ \\
\hline & 157 & $940 \pm 8 c$ & $1.22 \pm 0.02 b$ & $6.0 \pm 0.2 b$ & $8.67 \pm 0.05 c$ & $44.63 \pm 0.07 b$ & $213.37 \pm 0.07 b$ \\
\hline & 170 & $949 \pm 7 a b$ & $0.78 \pm 0.01 h$ & $4.9 \pm 0.2 \mathrm{e}$ & $8.6 \pm 0.4 c$ & $36.9 \pm 0.4 \mathrm{k}$ & $174 \pm 1 j$ \\
\hline & 184 & $945 \pm 1 b c$ & $0.795 \pm 0.005 \mathrm{~g}$ & $5.68 \pm 0.01 c$ & $7.3 \pm 0.3 f$ & $41.0 \pm 0.2 \mathrm{~g}$ & $193.8 \pm 0.7 \mathrm{~g}$ \\
\hline & 198 & $939 \pm 1 c$ & $0.84 \pm 0.01 f$ & $6.27 \pm 0.01 a$ & $6.5 \pm 0.2 \mathrm{~g}$ & $47.3 \pm 0.1 a$ & $221.8 \pm 0.5 a$ \\
\hline \multicolumn{8}{|l|}{ Significance } \\
\hline \multicolumn{2}{|l|}{$C$} & NS & * & * & * & * & * \\
\hline \multicolumn{2}{|l|}{$\mathrm{T}$} & $*$ & * & * & * & * & * \\
\hline \multicolumn{2}{|l|}{$\mathrm{C} \times \mathrm{T}$} & NS & * & * & * & * & * \\
\hline \multicolumn{8}{|c|}{$\begin{array}{l}\text { Values are expressed as means } \pm \text { SD. Means in the same column followed by different Latin letters are significantly different according to Tukey's HSD } \\
\text { test }(P=0.05) \text {. } \\
\text { a 7-PE, 7-layer low density PE film; S-PE, single three-layer PE film; ID-PE, double inflated three-layer PE film. } \\
{ }^{*} \text { Significance at } P=0.05 ; \mathrm{NS} \text {, no significance. }\end{array}$} \\
\hline
\end{tabular}

with harvesting date which could be attributed to changing temperature and lighting conditions that increased respiration and water loss from fruit. The other nutritional value parameters (fat, ash, proteins, carbohydrates and energetic value) were affected by both factors (cover materials and harvesting date) with fat and carbohydrates showing an increasing trend with harvesting date for all the tested cover materials. Moreover, the highest values for both parameters were observed for the last harvest and ID-PE material, which also resulted in the highest energetic value of fruit. Tocopherol composition is presented in Table 2. All tocopherol forms were detected in tomato fruit, with the highest content of total and individual vitamers being observed in plants grown in the greenhouse covered with ID-PE material, especially at late harvest dates (170 DAT and older). $\alpha$-Tocopherol was the main tocopherol, followed by $\gamma-, \beta$ - and $\delta$-tocopherols which were detected in lower amounts.

Regarding sugar composition, fructose and glucose were the only detected sugars, with their highest content being observed for S-PE cover material and harvesting at 157 DAT (Table 3). Moreover, fructose/glucose ratio was slightly higher than 1.0, indicating similar amounts of both sugars, while the highest content of sugars coincided with high total soluble solids (TSS) content, although no significant effect on this quality parameter was recorded for either the studied cover materials or harvesting dates.

Organic acid composition is presented in Table 4. Citric acid was the major organic acid in tomato fruit, followed by malic, oxalic and ascorbic acids. Individual and total organic acid content, especially citric acid, exhibited decreasing trends with succession of harvesting, except for malic acid where fluctuating trends were observed.

Sugar/acid ratio varied significantly among the studied cover materials and harvesting dates (5.9-14.2), with highest values being observed for ID-PE and the last harvesting date, indicating better taste and fruit quality (Table 4). Moreover, an increasing trend of ratio values was observed at harvests taking place at later growth stages which could be attributed to improving light conditions, especially for S-PE and ID-PE cover materials, as well as to increasing temperatures which probably resulted in stressful conditions for tomato plants.

Fatty acid composition is presented in Table 5. The most abundant fatty acids were linoleic and palmitic acids, with significant variation being observed in relation to harvesting date and cover material (30.66-53.15 and $14.98-23.85 \%$, respectively), whereas $\alpha$-linolenic, oleic, stearic and eicosapentaenoic acids were detected in lower amounts. Polyunsaturated fatty acids (PUFA) were the most abundant class of fatty acids contributing up to $60.4 \%$ of total fatty acids, while PUFA/saturated fatty acids (SFA) ratio was higher than 0.45 in all the cases. Moreover, $n-6 / n-3$ ratio gradually increased with harvesting time for 7-PE and S-PE cover materials, being higher than 4.0 at 157 and 138 DAT, respectively, while for ID-PE material ratio values remained lower than 4.0 throughout the growing period.

Antioxidant properties were determined with four different assays and the results are presented in Table 6. The effect of harvesting date and cover material showed a varied response on antioxidant properties of tomato fruit depending on the assay. In particular, the lowest $\mathrm{EC}_{50}$ values for reducing power assay were recorded for 7-PE and S-PE cover materials and 170 and 137 DAT, respectively, while for TBARS assay only S-PE showed the best antioxidant properties (at 137 DAT). For DPPH assay, fruit harvested at 198 DAT from plants grown under S-PE cover material showed the best results, whereas for $\beta$-carotene assay harvesting at 184 and 198DAT for both 7-PE and S-PE cover materials had the highest antioxidant properties. 
Table 2. Composition in tocopherols $\left(\mathrm{mg} \mathrm{kg}^{-1} \mathrm{fw}\right)$ of tomato fruit in relation to cover material and harvest date (days after transplantation, DAT). Values are expressed as means \pm SD

\begin{tabular}{|c|c|c|c|c|c|c|}
\hline Cover material (C) & $\operatorname{DAT}(\mathrm{T})$ & $\alpha$-Tocopherol & $\beta$-Tocopherol & $\gamma$-Tocopherol & $\delta$-Tocopherol & Total tocopherols \\
\hline \multirow{5}{*}{ 7-PE } & 137 & $1.38 \pm 0.04 j$ & $0.076 \pm 0.002 f$ & $0.88 \pm 0.02 f$ & $0.051 \pm 0.002 b c$ & $2.39 \pm 0.06 i$ \\
\hline & 157 & $1.06 \pm 0.011$ & $0.080 \pm 0.001 f$ & $0.81 \pm 0.03 \mathrm{~g}$ & $0.031 \pm 0.002 \mathrm{e}$ & $1.98 \pm 0.041$ \\
\hline & 170 & $1.97 \pm 0.01 \mathrm{e}$ & $0.126 \pm 0.002 b$ & $0.87 \pm 0.05 f$ & $0.053 \pm 0.004 b$ & $3.02 \pm 0.06 \mathrm{e}$ \\
\hline & 184 & $2.21 \pm 0.01 b$ & $0.118 \pm 0.003 c$ & $0.95 \pm 0.02 e$ & $0.045 \pm 0.002 c$ & $3.33 \pm 0.01 b$ \\
\hline & 198 & $1.39 \pm 0.01 \mathrm{k}$ & $0.078 \pm 0.001 f$ & $0.35 \pm 0.02 k$ & $0.015 \pm 0.001 \mathrm{~g}$ & $1.83 \pm 0.01 \mathrm{~m}$ \\
\hline \multirow{5}{*}{ S-PE } & 137 & $1.38 \pm 0.02 j$ & $0.077 \pm 0.002 f$ & $0.722 \pm 0.008 j$ & $0.048 \pm 0.002 b c$ & $2.22 \pm 0.01 \mathrm{k}$ \\
\hline & 157 & $1.70 \pm 0.01 \mathrm{~g}$ & $0.092 \pm 0.004 \mathrm{ef}$ & $0.938 \pm 0.001 e$ & $0.023 \pm 0.001 f$ & $2.75 \pm 0.01 \mathrm{~g}$ \\
\hline & 170 & $1.51 \pm 0.02 \mathrm{~h}$ & $0.090 \pm 0.003 e$ & $1.00 \pm 0.02 d$ & $0.048 \pm 0.001 b c$ & $2.65 \pm 0.04 h$ \\
\hline & 184 & $2.05 \pm 0.02 d$ & $0.100 \pm 0.001 d$ & $0.731 \pm 0.003 j$ & $0.028 \pm 0.001 \mathrm{e}$ & $2.91 \pm 0.01 f$ \\
\hline & 198 & $1.98 \pm 0.02 e$ & $0.102 \pm 0.003 d$ & $0.763 \pm 0.004 i$ & $0.038 \pm 0.001 d$ & $2.89 \pm 0.01 f$ \\
\hline \multirow{5}{*}{ ID-PE } & 137 & $1.43 \pm 0.01 i$ & $0.071 \pm 0.004 \mathrm{~g}$ & $0.79 \pm 0.01 \mathrm{gh}$ & $0.047 \pm 0.002 c$ & $2.35 \pm 0.01 j$ \\
\hline & 157 & $2.10 \pm 0.01 c$ & $0.099 \pm 0.003 d$ & $1.06 \pm 0.02 c$ & $0.052 \pm 0.007 b$ & $3.31 \pm 0.01 b$ \\
\hline & 170 & $1.85 \pm 0.03 f$ & $0.104 \pm 0.004 d$ & $1.19 \pm 0.03 a$ & $0.049 \pm 0.002 b c$ & $3.19 \pm 0.01 c$ \\
\hline & 184 & $1.84 \pm 0.02 f$ & $0.103 \pm 0.003 d$ & $1.13 \pm 0.02 b$ & $0.072 \pm 0.002 a$ & $3.14 \pm 0.04 d$ \\
\hline & 198 & $2.65 \pm 0.01 a$ & $0.147 \pm 0.005 a$ & $0.78 \pm 0.02 \mathrm{hi}$ & $0.029 \pm 0.001 e$ & $3.60 \pm 0.01 a$ \\
\hline \multicolumn{7}{|l|}{ Significance } \\
\hline C & & * & * & * & * & * \\
\hline $\mathrm{T}$ & & * & * & * & * & * \\
\hline $\mathrm{C} \times \mathrm{T}$ & & * & * & * & * & * \\
\hline
\end{tabular}

Table 3. Composition in sugar $\left(\mathrm{g} \mathrm{kg}^{-1} \mathrm{fw}\right.$ ) and TSS ( ${ }^{\circ}$ Brix) of tomato fruit in relation to cover material and harvest date (days after transplantation, DAT). Values are expressed as means $\pm S D$

\begin{tabular}{|c|c|c|c|c|c|c|}
\hline Cover material (C) & $\mathrm{DAT}(\mathrm{T})$ & Fructose & Glucose & Total sugars & Fructose/glucose & TSS \\
\hline \multirow{5}{*}{ 7-PE } & 137 & $12.0 \pm 0.21$ & $11.7 \pm 0.2 \mathrm{j}$ & $23.7 \pm 0.41$ & $1.034 \pm 0.003 f$ & 4.9 \\
\hline & 157 & $15.08 \pm 0.06 e$ & $13.12 \pm 0.05 g$ & $28.20 \pm 0.01 \mathrm{~g}$ & $1.150 \pm 0.005 a$ & 4.5 \\
\hline & 170 & $15.12 \pm 0.05 e$ & $13.9 \pm 0.1 e$ & $29.0 \pm 0.2 \mathrm{e}$ & $1.088 \pm 0.004 d$ & 4.8 \\
\hline & 184 & $14.7 \pm 0.1 \mathrm{~g}$ & $13.54 \pm 0.07 f$ & $28.27 \pm 0.06 f g$ & $1.09 \pm 0.01 d$ & 4.9 \\
\hline & 198 & $15.06 \pm 0.05 \mathrm{e}$ & $13.92 \pm 0.03 e$ & $29.99 \pm 0.08 e$ & $1.008 \pm 0.001 d$ & 5.1 \\
\hline \multirow{5}{*}{ S-PE } & 137 & $12.4 \pm 0.2 \mathrm{k}$ & $11.2 \pm 0.1 \mathrm{k}$ & $23.6 \pm 0.31$ & $1.107 \pm 0.007 c$ & 5.0 \\
\hline & 157 & $18.2 \pm 0.1 \mathrm{a}$ & $16.1 \pm 0.1 \mathrm{a}$ & $34.3 \pm 0.3 a$ & $1.128 \pm 0.001 b$ & 5.1 \\
\hline & 170 & $16.72 \pm 0.01 c$ & $14.8 \pm 0.3 d$ & $31.5 \pm 0.3 d$ & $1.13 \pm 0.02 b$ & 4.9 \\
\hline & 184 & $14.6 \pm 0.1 \mathrm{fg}$ & $13.9 \pm 0.1 \mathrm{e}$ & $28.52 \pm 0.01 f$ & $1.05 \pm 0.01 f$ & 4.9 \\
\hline & 198 & $14.2 \pm 0.2 \mathrm{~h}$ & $13.28 \pm 0.08 \mathrm{~g}$ & $27.5 \pm 0.3 \mathrm{~h}$ & $1.068 \pm 0.001 \mathrm{e}$ & 5.1 \\
\hline \multirow{5}{*}{ ID-PE } & 137 & $13.5 \pm 0.2 i$ & $11.9 \pm 0.2 \mathrm{i}$ & $25.3 \pm 0.3 \mathrm{k}$ & $1.131 \pm 0.002 b$ & 5.0 \\
\hline & 157 & $17.52 \pm 0.09 b$ & $15.7 \pm 0.2 c$ & $33.3 \pm 0.3 b$ & $1.113 \pm 0.005 c$ & 4.9 \\
\hline & 170 & $14.49 \pm 0.08 \mathrm{~g}$ & $12.5 \pm 0.3 \mathrm{~h}$ & $27.0 \pm 0.4 \mathrm{i}$ & $1.16 \pm 0.01 a$ & 4.9 \\
\hline & 184 & $13.4 \pm 0.2 \mathrm{i}$ & $12.6 \pm 0.2 \mathrm{~h}$ & $26.0 \pm 0.4 j$ & $1.068 \pm 0.004 \mathrm{e}$ & 5.0 \\
\hline & 198 & $16.11 \pm 0.02 d$ & $15.93 \pm 0.03 b$ & $32.04 \pm 0.05 c$ & $1.011 \pm 0.001 \mathrm{~g}$ & 5.4 \\
\hline \multicolumn{7}{|l|}{ Significance } \\
\hline$C$ & & * & * & * & * & NS \\
\hline $\mathrm{T}$ & & * & * & * & * & NS \\
\hline $\mathrm{C} \times \mathrm{T}$ & & * & * & * & * & NS \\
\hline
\end{tabular}




\begin{tabular}{|c|c|c|c|c|c|c|c|}
\hline Cover material (C) & $\mathrm{DAT}(\mathrm{T})$ & Oxalic acid & Malic acid & Ascorbic acid & Citric acid & Total organic acids & Sugars/acids \\
\hline \multirow{6}{*}{ 7-PE } & 137 & $0.290 \pm 0.003 a$ & $0.520 \pm 0.005 c$ & $0.080 \pm 0.001 \mathrm{~g}$ & $3.06 \pm 0.05 c$ & $3.95 \pm 0.06 a$ & $5.994 \pm 0.008 k$ \\
\hline & 157 & $0.120 \pm 0.005 c$ & $0.380 \pm 0.001 \mathrm{~h}$ & $0.090 \pm 0.001 f$ & $2.98 \pm 0.02 d$ & $3.57 \pm 0.02 d$ & $7.90 \pm 0.02 h$ \\
\hline & 170 & $0.020 \pm 0.001 e$ & $0.340 \pm 0.005 i$ & $0.120 \pm 0.001 c$ & $3.19 \pm 0.09 b$ & $3.67 \pm 0.09 c$ & $7.9 \pm 0.1 \mathrm{~h}$ \\
\hline & 184 & $0.040 \pm 0.001 d$ & $0.560 \pm 0.002 a$ & $0.130 \pm 0.001 b$ & $2.67 \pm 0.06 f$ & $3.40 \pm 0.06 e$ & $8.3 \pm 0.1 \mathrm{~g}$ \\
\hline & 198 & $0.010 \pm 0.001 \mathrm{f}$ & $0.500 \pm 0.001 d$ & $0.120 \pm 0.001 c$ & $2.48 \pm 0.02 \mathrm{~g}$ & $3.11 \pm 0.02 f$ & $9.31 \pm 0.06 \mathrm{e}$ \\
\hline & 137 & $0.120 \pm 0.005 c$ & $0.560 \pm 0.006 a$ & $0.070 \pm 0.001 \mathrm{~h}$ & $3.24 \pm 0.08 b$ & $3.99 \pm 0.09 a$ & $5.89 \pm 0.03 k$ \\
\hline \multirow{4}{*}{ S-PE } & 157 & $\operatorname{tr}$ & $0.330 \pm 0.002 j$ & $0.110 \pm 0.001 d$ & $2.53 \pm 0.03 \mathrm{~g}$ & $2.97 \pm 0.03 g$ & $11.56 \pm 0.01 b$ \\
\hline & 170 & $\operatorname{tr}$ & $0.400 \pm 0.002 \mathrm{~g}$ & $0.130 \pm 0.001 b$ & $2.92 \pm 0.01 d$ & $3.45 \pm 0.02 e$ & $9.1 \pm 0.1 \mathrm{e}$ \\
\hline & 184 & $0.010 \pm 0.001 f$ & $0.480 \pm 0.001 \mathrm{e}$ & $0.130 \pm 0.001 b$ & $2.15 \pm 0.05 i$ & $2.77 \pm 0.06 h$ & $10.3 \pm 0.1 c$ \\
\hline & 198 & $0.010 \pm 0.001 f$ & $0.460 \pm 0.007 f$ & $0.130 \pm 0.001 b$ & $2.2 \pm 0.1 \mathrm{~h}$ & $2.8 \pm 0.2 h$ & $9.7 \pm 0.4 d$ \\
\hline \multirow{5}{*}{ ID-PE } & 137 & $0.210 \pm 0.002 b$ & $0.520 \pm 0.007 b c$ & $0.060 \pm 0.001 i$ & $2.77 \pm 0.02 \mathrm{e}$ & $3.56 \pm 0.03 d$ & $7.10 \pm 0.02 j$ \\
\hline & 157 & $0.010 \pm 0.001 f$ & $0.280 \pm 0.005 \mid$ & $0.130 \pm 0.001 b$ & $3.37 \pm 0.01 a$ & $3.79 \pm 0.02 b$ & $8.79 \pm 0.07 f$ \\
\hline & 170 & $0.010 \pm 0.001 f$ & $0.340 \pm 0.006 i$ & $0.100 \pm 0.001 e$ & $2.94 \pm 0.06 d$ & $3.39 \pm 0.07 e$ & $7.9 \pm 0.2 \mathrm{~h}$ \\
\hline & 184 & $0.040 \pm 0.001 d$ & $0.530 \pm 0.001 b$ & $0.110 \pm 0.001 d$ & $2.77 \pm 0.05 e$ & $3.45 \pm 0.05 e$ & $7.5 \pm 0.1 \mathrm{i}$ \\
\hline & 198 & $\operatorname{tr}$ & $0.320 \pm 0.002 \mathrm{k}$ & $0.150 \pm 0.001 a$ & $1.78 \pm 0.03 j$ & $2.25 \pm 0.03 i$ & $14.2 \pm 0.1 \mathrm{a}$ \\
\hline \multicolumn{8}{|l|}{ Significance } \\
\hline C & & * & * & * & * & * & * \\
\hline $\mathrm{T}$ & & * & * & * & * & * & * \\
\hline $\mathrm{C} \times \mathrm{T}$ & & * & * & * & * & * & * \\
\hline
\end{tabular}

Fruit pigment content is presented in Table 7. Lycopene was the main detected carotenoid, followed by $\beta$-carotene. Total carotenoid and $\beta$-carotene contents were higher for 7-PE material and harvesting at 184 DAT, whereas lycopene was the highest for S-PE material and 157 DAT. In addition, individual and total chlorophyll content fluctuated during the growing season for all the studied materials, while the highest contents were detected for 7-PE material and early harvestings (137-157 DAT).

\section{DISCUSSION}

\section{Growth parameters and total yield}

Mean fruit weight was not affected by cover material or harvesting date in our study. However, total yield showed significant differences among the studied cover materials. According to Pratta et al. ${ }^{25}$ fruit weight is not dependent on growth conditions and is considered a yield parameter that is highly affected by genotype, fruit load and competition between fruit and leaves for biosynthetic assimilates. ${ }^{26}$ Considering that in our study clusters of fruit were thinned to the same fruit number $\left(5\right.$ fruits truss $\left.{ }^{-1}\right)$, this could explain the insignificant effect of cover material and harvest date on fruit size. In contrast to our study, Gul et al. ${ }^{18}$ who studied the effect of PE and glass as greenhouse cover materials under Mediterranean climate conditions did not report significant differences in total yield since they harvested the same number of fruit clusters per plant in both environments. The significant effect of cover material in our study could be attributed partly to different properties of the studied materials (light diffusion and transmission of infrared radiation), which resulted in different total number of fruit clusters per plant among the studied materials due to earliness in fruit ripening and reduction of fruit load.

\section{Fuel consumption}

Regarding the relation of energy consumption to greenhouse materials, energy savings from double PE films in greenhouse vegetable production have been highlighted by Papadopoulos and $\mathrm{HaO}^{27}$ who also suggested the use of supplemental light to compensate for lower light intensities under such cover materials. ${ }^{7}$ Moreover, the reports from our study confirm these results and also support the use of new cover materials such as 7-PE for further energy savings and lower production costs, especially nowadays where heating cost has become an essential component of total production cost and support green crop production.

\section{Chemical composition}

Nutritional value of tomato fruit was significantly affected by both factors (cover materials and harvesting date), especially regarding fat and carbohydrate content. Although nutritional value of tomato fruit is highly associated with genotype and cultivar group, ${ }^{28}$ manipulation of growth conditions within controlled environments may help to enhance nutritional value and increase tomato fruit quality. ${ }^{29}$

Similar results to our study regarding tocopherol composition of tomato fruit have been reported by Pék et al. ${ }^{30}$ who detected significant amounts of $\alpha$ - and $\gamma$-tocopherols, without however detecting $\delta$-tocopherol, as was the case in our study. The effect of light conditions on tocopherol content of vegetables grown in protected environments has been suggested in several reports, especially regarding leafy vegetables such as lettuce $e^{31,32}$ and greens, $^{33}$ since tocopherol biosynthesis is indirectly affected by light stimulus. ${ }^{34}$ Therefore, cover materials with different optical properties are expected to affect tocopherol content and composition in tomato fruit, especially for the early harvested clusters. However, for later harvests complex effects of light intensity and stress conditions due to high temperatures may be also observed. 


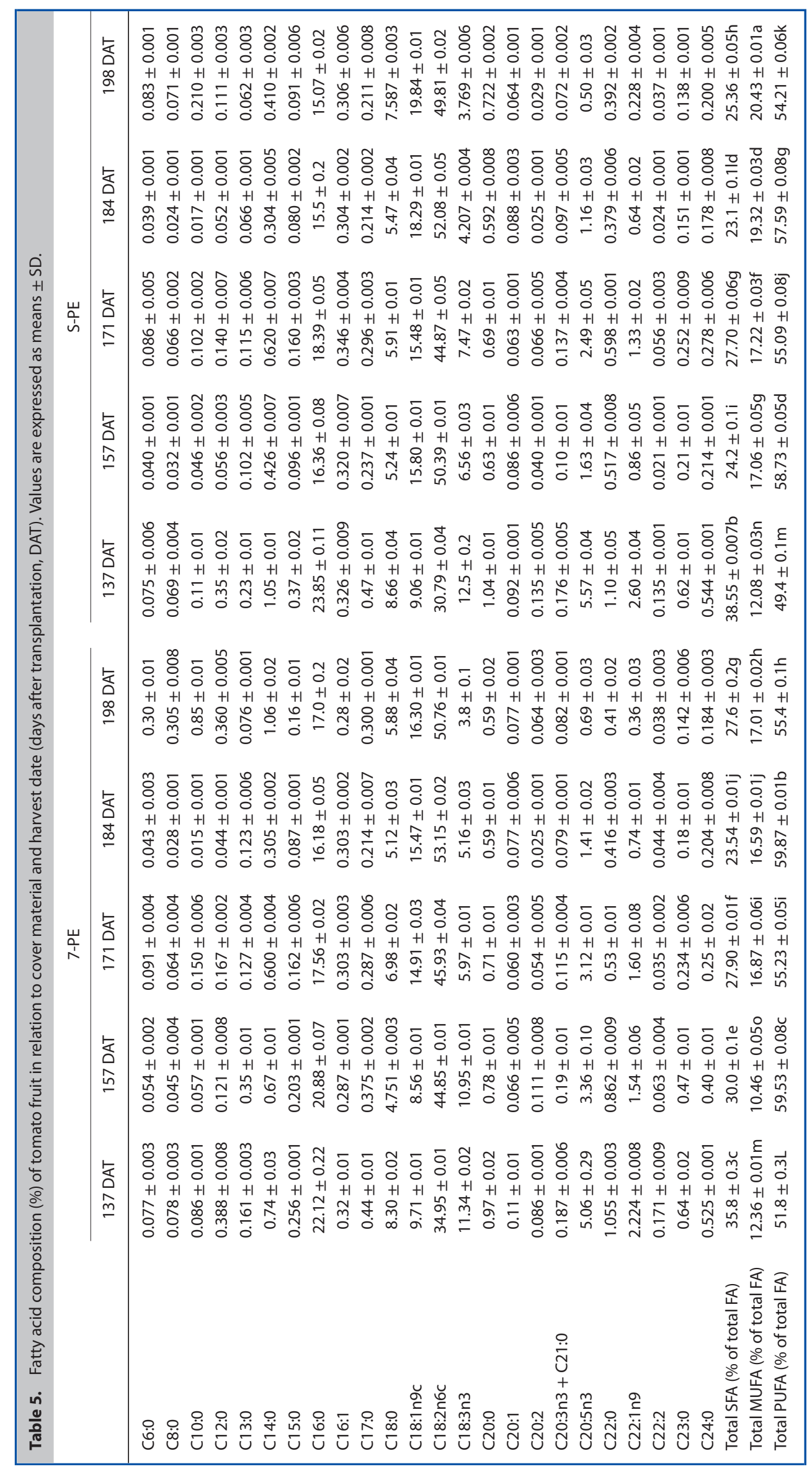




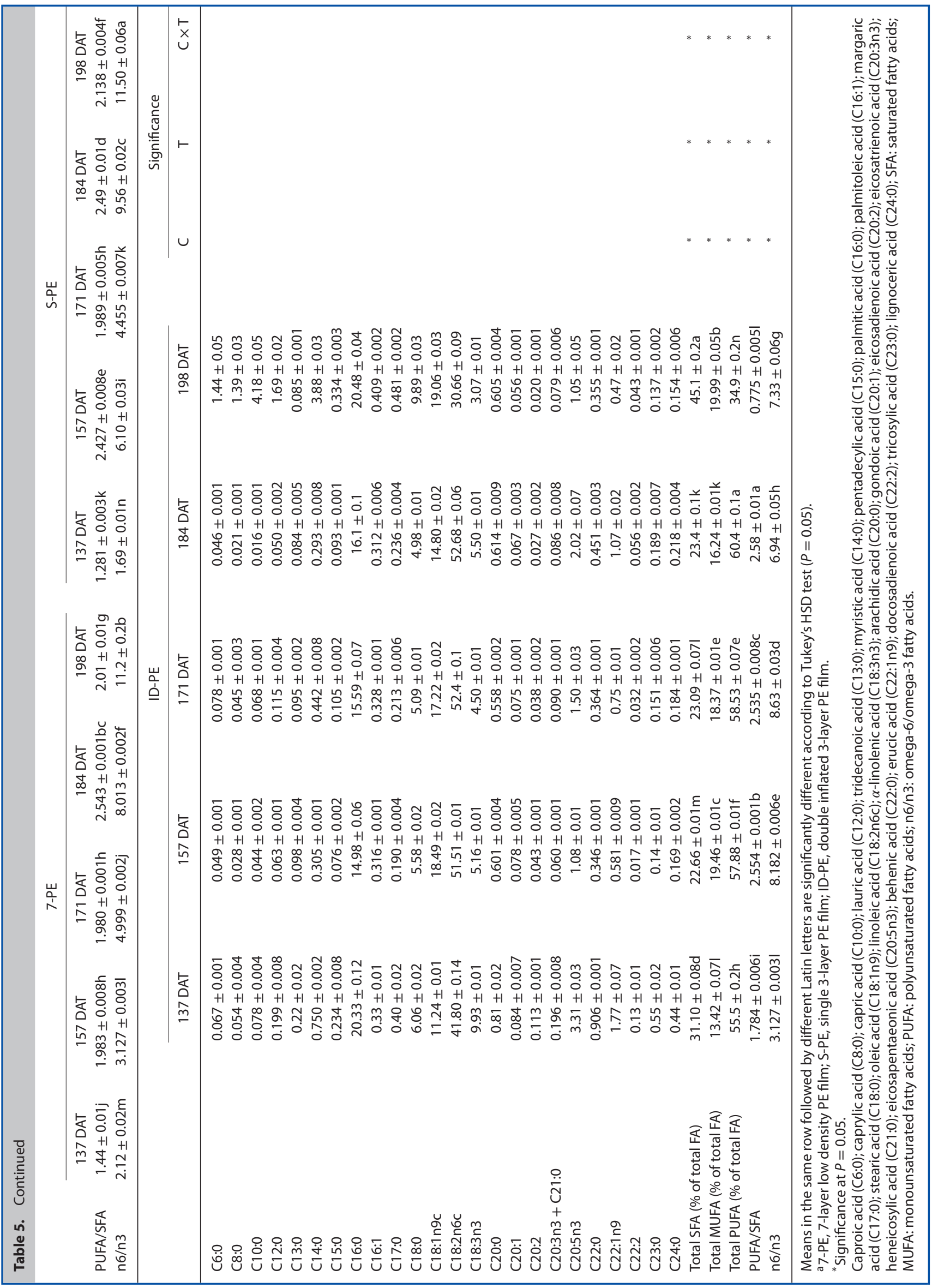




\begin{tabular}{|c|c|c|c|c|c|}
\hline \multirow[b]{2}{*}{$\begin{array}{l}\text { Cover } \\
\text { material (C) }\end{array}$} & \multirow[b]{2}{*}{$\operatorname{DAT}(\mathrm{T})$} & \multirow{2}{*}{$\begin{array}{l}\text { Reducing power } \\
\text { Ferricyanide/Prussian blue } \\
\left(\mathrm{EC}_{50} ; \mathrm{mg} \mathrm{mL}^{-1}\right)\end{array}$} & \multicolumn{2}{|c|}{ Radical scavenging activity } & \multirow{2}{*}{$\begin{array}{c}\text { Lipid peroxidation inhibition } \\
\text { TBARS } \\
\left(\mathrm{EC}_{50} ; \mathrm{mg} \mathrm{mL}^{-1}\right)\end{array}$} \\
\hline & & & $\begin{array}{l}\text { DPPH scavenging activity } \\
\qquad\left(\mathrm{EC}_{50} ; \mathrm{mg} \mathrm{mL}^{-1}\right)\end{array}$ & $\begin{array}{c}\beta \text {-Carotene/linoleate } \\
\left(\mathrm{EC}_{50} ; \mathrm{mg} \mathrm{mL}^{-1}\right)\end{array}$ & \\
\hline \multirow{5}{*}{ 7-PE } & 137 & $1.40 \pm 0.04 i$ & $9.3 \pm 0.1 b$ & $0.77 \pm 0.01 b$ & $0.212 \pm 0.007 \mathrm{~g}$ \\
\hline & 157 & $1.42 \pm 0.01 \mathrm{~h}$ & $9.25 \pm 0.03 b$ & $0.73 \pm 0.04 \mathrm{de}$ & $0.251 \pm 0.001 b$ \\
\hline & 170 & $1.31 \pm 0.01 j$ & $9.00 \pm 0.05 c$ & $0.67 \pm 0.03 \mathrm{hi}$ & $0.209 \pm 0.005 \mathrm{gh}$ \\
\hline & 184 & $1.44 \pm 0.01 \mathrm{~g}$ & $7.2 \pm 0.2 \mathrm{e}$ & $0.65 \pm 0.01 \mathrm{ik}$ & $0.230 \pm 0.001 e$ \\
\hline & 198 & $1.46 \pm 0.01 \mathrm{ef}$ & $6.66 \pm 0.04 f$ & $0.64 \pm 0.01 \mathrm{k}$ & $0.231 \pm 0.004 \mathrm{de}$ \\
\hline \multirow{5}{*}{ S-PE } & 137 & $1.32 \pm 0.01 j$ & $9.8 \pm 0.3 a$ & $0.73 \pm 0.04 \mathrm{def}$ & $0.188 \pm 0.001 i$ \\
\hline & 157 & $1.43 \pm 0.01 \mathrm{gh}$ & $9.24 \pm 0.04 b$ & $0.80 \pm 0.02 a$ & $0.213 \pm 0.004 \mathrm{~g}$ \\
\hline & 170 & $1.60 \pm 0.01 d$ & $8.4 \pm 0.1 d$ & $0.70 \pm 0.05 f g$ & $0.223 \pm 0.009 f$ \\
\hline & 184 & $1.47 \pm 0.02 \mathrm{e}$ & $6.14 \pm 0.06 \mathrm{~g}$ & $0.64 \pm 0.01 \mathrm{k}$ & $0.227 \pm 0.002 \mathrm{ef}$ \\
\hline & 198 & $1.42 \pm 0.01 \mathrm{~h}$ & $5.8 \pm 0.2 i$ & $0.66 \pm 0.02 i k$ & $0.255 \pm 0.003 a b$ \\
\hline \multirow{5}{*}{ ID-PE } & 137 & $1.45 \pm 0.02 \mathrm{fg}$ & $9.17 \pm 0.04 b$ & $0.75 \pm 0.01 b c$ & $0.241 \pm 0.005 c$ \\
\hline & 157 & $1.63 \pm 0.02 c$ & $8.7 \pm 0.2$ & $0.75 \pm 0.03 c d$ & $0.205 \pm 0.005 h$ \\
\hline & 170 & $1.78 \pm 0.02 a$ & $8.33 \pm 0.06 d$ & $0.69 \pm 0.01 \mathrm{gh}$ & $0.235 \pm 0.005 d$ \\
\hline & 184 & $1.76 \pm 0.01 b$ & $7.18 \pm 0.07 e$ & $0.67 \pm 0.01 \mathrm{hi}$ & $0.229 \pm 0.005 e$ \\
\hline & 198 & $1.64 \pm 0.01 c$ & $5.9 \pm 0.2 \mathrm{~h}$ & $0.72 \pm 0.02 \mathrm{ef}$ & $0.259 \pm 0.005 a$ \\
\hline \multicolumn{2}{|l|}{ Significance } & & & & \\
\hline \multicolumn{2}{|l|}{$C$} & * & * & * & * \\
\hline \multicolumn{2}{|l|}{$\mathrm{T}$} & * & * & * & * \\
\hline \multicolumn{2}{|l|}{$\mathrm{C} \times \mathrm{T}$} & * & * & * & * \\
\hline
\end{tabular}

The findings of our study regarding sugar composition are in agreement with the study of Krumbein and Schwarz ${ }^{35}$ who also reported fructose and glucose as the most important soluble sugars in tomato fruit. Similarly, Farneti et al. ${ }^{36}$ reported a monthly variation in sugar levels of tomato fruit grown in greenhouses with different cooling systems and further concluded that sugar content was not affected by greenhouse type and climate conditions. In addition, Papaioannou et al. ${ }^{17}$ did not find a significant effect of PE cover materials on TSS content of tomato fruit. In addition, Toor et al. ${ }^{37}$ detected a great variation in TSS content during the growing season for three greenhouse-grown tomato genotypes suggesting a genotype-dependent effect. In contrast to our study, Georgelis et al. ${ }^{38}$ suggested that sugar content was positively correlated with soluble solid and organic acid contents. Moreover, the same authors suggested a negative correlation between sugar content and early maturity of fruit, which was also the case for fruit harvested at 137 DAT in our study. ${ }^{38}$ Therefore, the different response of sugars to soluble solids content found in our study could be attributed probably to the fact that fruit were harvested according to visual appearance, marketable size and the number of days after transplantation, instead of taking into account the number of days after anthesis which was implemented in the study of Georgelis et al. ${ }^{38}$ Moreover, according to Young et al. ${ }^{39}$ fruit colour and visual appearance are better indicators of fruit developmental stage than number of days after anthesis. Environmental factors may have a crucial effect on colour development due to acceleration in carotenoid biosynthesis and chlorophyll breakdown and therefore in earliness of ripening and reduced sugar content. ${ }^{38}$

The increase of organic acid content with succession of harvesting has been also suggested in the report of Farneti et al., ${ }^{36}$ especially when cool air was applied below growing gutters allowing for lower air temperatures close to fruit clusters. Moreover, in agreement with the results reported by Georgelis et al., ${ }^{38}$ the highest value of TSS content in our study coincided with the highest organic acid content (Tables 3 and 4). This result confirms the positive correlation between these two fruit quality parameters, as well as the significant contribution of other soluble constituents to ${ }^{\circ}$ Brix values than sugars alone. However, this is not always the case since according to George et al. ${ }^{40}$ a great variation exists among different tomato genotypes for both parameters (TSS and organic acids) without the trends in TSS content following those of titratable acidity values.

Fluctuating values of sugars/acids ratio and higher values during the warmer and brighter growing periods (late spring-summer) have been reported by Gautier et al. ${ }^{16}$ who also suggested fluctuating values of sugars/acids ratio and generally higher values during the summer period. In addition, Farneti et al. ${ }^{36}$ attributed the increase in sugars/acids ratio values to higher sucrose synthase activity and hexose contents under higher temperatures and irradiation levels. The recorded values in our study were lower than those reported by Ullah et al. ${ }^{41}$ and Luo and $\mathrm{Li}^{42}$ who studied tomato fruit quality under different nutrient and irrigation regimes. Moreover, according to Luo and $\mathrm{Li}^{42}$ and Zhai et al., ${ }^{43}$ stress conditions due to water deficit and salinity, respectively, may result in higher sugars/acids ratio and better fruit quality.

Similar results to our study regarding fatty acid composition of tomato fruit have been previously reported by Khan et al., ${ }^{29}$ although with different amounts of individual fatty acids being detected. PUFA/SFA and $n 6 / n 3$ ratios in tomato fruit of our study indicate a good nutritional value of tomato fruit regardless of harvesting date and cover material. ${ }^{44}$ According to Guil et al., ${ }^{44} n-6 / n-3$ 


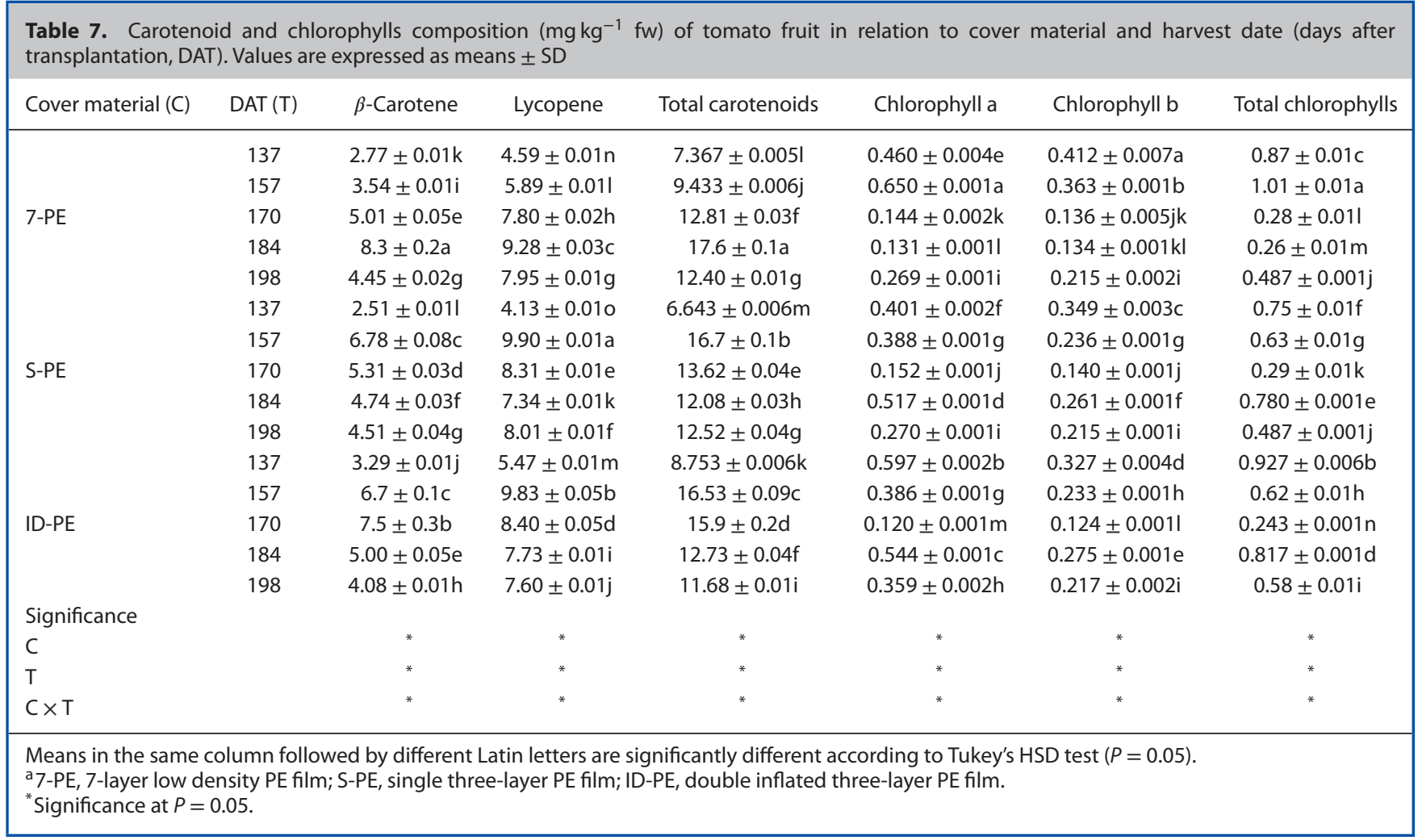

values lower than 4.0 indicate high nutritional value and beneficial health effects, which further highlights the importance of growing conditions for nutritional value and quality of tomato fruit.

The observed differences in antioxidant properties of tomato fruit depending on the implemented assay were expected, since according to Floegel et al., ${ }^{45}$ the results of antioxidant capacity measurements may differ among the implemented assays because they employ different principles. The same authors also suggested that DPPH assay was in good agreement with ABTS assay for tomato fruit and products..$^{45}$ Moreover, Toor et al. ${ }^{37}$ and Ahmadi et $a l .{ }^{46}$ reported significant variation in the major antioxidant compounds and antioxidant properties of tomato fruit grown under different cover materials, due to differences in irradiation, temperature and fruit load. Considering the differences in optical properties between the studied cover materials as well as in total fruit load (number of fruit clusters per plant), these could explain the different results in antioxidant properties of fruit from different harvesting dates and cover materials in our study. In contrast, Gul et al. ${ }^{18}$ did not detect significant differences in antioxidant properties of tomato fruit in relation to cladding materials, but reported a significant effect of harvesting date.

Carotenoid content may be affected by cover materials, as previously reported by Jarquín-Enríquez et al. ${ }^{15}$ and Tinyane et al.. ${ }^{47}$ while Živanović et al. ${ }^{19}$ suggested that apart from cover materials climate conditions may also affect lycopene and $\beta$-carotene content of tomato fruit. Moreover, Ahmadi et al. ${ }^{46}$ reported that cover material may affect lycopene content in tomato fruit, although a varied response of the tested genotypes to different cover materials was also observed. According to Gautier et al., ${ }^{16}$ light conditions and temperature are involved in lycopene and $\beta$-carotene metabolism, with increasing light having beneficial effects, whereas temperatures between $21-26$ and $27-32^{\circ} \mathrm{C}$ resulted in a reduction of total carotenoid and lycopene contents, respectively. Moreover, fruit part also has an effect on lycopene content, with peels containing a higher amount of this carotenoid comparing to flesh, ${ }^{19}$ while a seasonal and genotypic variation has been also reported. ${ }^{37}$ Considering that fruit sampling in our study included parts of chopped whole fruit, this could partly explain the reported results.

Regarding chlorophylls, their content decreases with maturation, while high light intensities induce chlorophyll degradation due to inhibition of chloroplast formation. ${ }^{2}$ Chlorophyll content is also affected by air temperature, since, according to Gautier et al., ${ }^{16}$ temperatures between 27 and $32{ }^{\circ} \mathrm{C}$ decreased chlorophyll degradation and consequently delayed fruit coloration and ripening process. Moreover, Živanović et al. ${ }^{19}$ reported a significant effect of cover material on chlorophyll content, although this effect was not consistent throughout a 3-year experiment. Therefore, chlorophyll content is highly associated with environmental conditions and cover materials may affect degradation rate of chlorophyll and consequently pigmentation of fruit and earliness of maturity.

\section{CONCLUSIONS}

Total yield showed significant differences among the studied cover materials, with S-PE material having the highest yield, compared to 7-PE and ID-PE materials. However, although S-PE had the highest yield, it also had the highest fuel consumption, which increases the production cost and eliminates any benefits from yield increases. Moreover, both new cover materials and harvesting dates may affect significantly tomato fruit quality, especially sugar and organic acid contents and sugars/acids ratio which are associated with fruit taste, tocopherol content which contributes to antioxidant properties and pigments that are associated with fruit ripening and earliness of marketable maturity. Therefore, the use of new cover materials may not 
only significantly reduce production cost and alleviate negative effects on total yield, but it also may increase fruit quality through the combination of proper harvesting date.

\section{ACKNOWLEDGEMENTS}

The authors are grateful to the Foundation for Science and Technology (FCT, Portugal) and FEDER under programme PT2020 for financial support to CIMO (UID/AGR/00690/2013), A. Fernandes grant (SFRH/BPD/114753/2016) and L. Barros contract.

\section{REFERENCES}

1 Cocetta G, Casciani D, Bulgari R, Musante F, Kolton A, Rossi M et al., Light use efficiency for vegetables production in protected and indoor environments. Eur Phys J Plus 132:1 - 15 (2017).

2 Ilić ZS and Fallik E, Light quality manipulation improves vegetable quality at harvest and postharvest: a review. Environ Exp Bot 139:79-90 (2017).

3 Al-Mahdouri A, Baneshi M, Gonome H, Okajima J and Maruyama S, Evaluation of optical properties and thermal performances of different greenhouse covering materials. Sol Energy 96:21 - 32 (2013).

4 Kittas C, Tchamitchian M, Katsoulas N, Karaiskou P and Papaioannou C, Effect of two UV-absorbing greenhouse-covering films on growth and yield of an eggplant soilless crop. Sci Hortic 110:30-37 (2006).

5 Murakami K, Fukuoka N and Noto S, Improvement of greenhouse microenvironment and sweetness of melon (Cucumis melo L.) fruits by greenhouse shading with a new kind of near-infrared ray-cutting net in mid-summer. Sci Hortic 218:1 - 7 (2017).

6 Ilić ZS, Milenković L, Stanojević L and Fallikc E, Effects of the modification of light intensity by color shade nets on yield and quality of tomato fruits. Sci Hortic 139:90-95 (2012).

7 Hao $X$ and Papadopoulos AP, Effects of supplemental lighting and cover materials on growth, photosynthesis, biomass partitioning, early yield and quality of greenhouse cucumber. Sci Hortic 80:1 - 18 (1999).

8 Fan X, Xu Z, Liu X, Tang C, Wang L and Han X, Effects of light intensity on the growth and leaf development of young tomato plants grown under a combination of red and blue light. Sci Hortic 153:50-55 (2013).

9 Fu W, Li P and Wu Y, Effects of different light intensities on chlorophyll fluorescence characteristics and yield in lettuce. Sci Hortic 135:45-51 (2012).

10 Casierra-Posada F, Zapata-Casierra E and Blanke MM, Accelerating the growth and increasing the nutritional value of chard (Beta vulgaris L. var. cicla) by applying yellow coloured filters. Eur J Hortic Sci 80:263-270 (2015).

11 Adegoroye AS and Jolliffe PA, Some inhibitory effects of radiation stress on tomato fruit ripening. J Sci Food Agric 39:297-302 (1987).

12 Dumas Y, Dadomo M, Di Lucca G and Grolier P, Effects of environmental factors and agricultural techniques on antioxidant content of tomatoes. J Sci Food Agric 83:369-382 (2003).

13 Sams CE, Preharvest factors affecting postharvest texture. Postharvest Biol Technol 15:249-254 (1999).

14 Hao X, Zheng JM, Zhang Y, Little C and Khosla S, Effects of diffused plastic cover materials on greenhouse microclimate, plant growth, fruit yield and quality, and energy use in greenhouse fruit vegetable production. Acta Hortic 1182:73-78 (2017).

15 Jarquín-Enríquez L, Mercado-Silva EM, Maldonado JL and LopezBaltazar J, Lycopene content and color index of tomatoes are affected by the greenhouse cover. Sci Hortic 155:43-48 (2013).

16 Gautier H, Diakou-Verdin V, Bénard C, Reich M, Buret M, Bourgaud F et al., How does tomato quality (sugar, acid, and nutritional quality) vary with ripening stage, temperature, and irradiance? J Agric Food Chem 56:1241-1250 (2008).

17 Papaioannou C, Katsoulas N, Maletsika P, Siomos A and Kittas C, Effects of a UV-absorbing greenhouse covering film on tomato yield and quality. Spanish J Agric Res 10:959 (2012).

18 Gul A, Sen F and Bonakdarzedeh M, Does greenhouse covering material affect fruit quality of hydroponic tomatoes? Acta Hortic 1107:237-243 (2015).

19 Živanović B, Vidović M, Komić SM and Jovanović L, Contents of phenolics and carotenoids in tomato grown under polytunnels with different UV-transmission rates. Turkish J Agric For 41:113-120 (2017).
20 Ombódi A, Pék Z, Szuvandzsiev P, Lugasi A, Ledóné Darázsi H and Helyes L, Effect of coloured shade nets on some nutritional characteristics of a kapia type pepper grown in plastic tunnel. Columella J Agric Environ Sci 3:25-33 (2016).

21 AOAC, Official methods of analysis of AOAC international, 20th edn, ed. by Horwitz W and Latimer G. AOAC International, Gaithersburg, MD (2016).

22 Barros L, Pereira E, Calhelha RC, Dueñas M, Carvalho AM, Santos-Buelga C etal., Bioactivity and chemical characterization in hydrophilic and lipophilic compounds of Chenopodium ambrosioides L. J Funct Foods 5:1732-1740 (2013).

23 Barros L, Pereira C and Ferreira ICFR, Optimized analysis of organic acids in edible mushrooms from Portugal by ultrafast liquid chromatography and photodiode array detection. Food Anal Methods 6:309-316 (2013).

24 Nagata M and Yamashita I, Simple method for simultaneous determination of chlorophyll and carotenoids in tomato fruit. Nippon Shokuhin Kogyo Gakkaishi 39:925-928 (1992).

25 Pratta GR, Rodriguez GR, Zorzoli R, Valle EM and Picardi LA, Molecular markers detect stable genomic regions underlying tomato fruit shelf life and weight. Crop Breed Appl Biotechnol 11:157-164 (2011).

26 Gautier H, Guichard S and Tchamitchian M, Modulation of competition between fruits and leaves by flower priming and water fogging, and consequences on tomato leaf and fruit growth. Ann Bot 88:645-652 (2001).

27 Papadopoulos AP and Hao X, Effects of greenhouse covers on seedless cucumber growth, productivity, and energy use. Sci Hortic 68:113-123 (1997).

28 Figàs MR, Prohens J, Raigón MD, Fita A, García-Martínez MD, Casanova $C$ et al., Characterization of composition traits related to organoleptic and functional quality for the differentiation, selection and enhancement of local varieties of tomato from different cultivar groups. Food Chem 187:517-524 (2015).

29 Khan I, Azam A and Mahmood A, The impact of enhanced atmospheric carbon dioxide on yield, proximate composition, elemental concentration, fatty acid and vitamin C contents of tomato (Lycopersicon esculentum). Environ Monit Assess 185:205-214 (2013).

30 Pék Z, Szuvandzsiev P, Daood H, Neményi A and Helyes L, Effect of irrigation on yield parameters and antioxidant profiles of processing cherry tomato. Cent Eur J Biol 9:383-395 (2014).

31 Samuolienè G, Sirtautas R, Brazaitytè A and Duchovskis P, LED lighting and seasonality effects antioxidant properties of baby leaf lettuce. Food Chem 134:1494-1499 (2012).

32 Samuolienè G, Brazaitytè A, Sirtautas R, Viršilè A, Sakalauskait J, Sakalauskienè $S$ et al., LED illumination affects bioactive compounds in romaine baby leaf lettuce. J Sci Food Agric 93:3286-3291 (2013).

33 Samuolienè G, Brazaitytè A, Viršilè A, Jankauskienè J, Sakalauskienè S and Duchovskis $\mathrm{P}$, Red light-dose or wavelength-dependent photoresponse of antioxidants in herb microgreens. PLoS One 11:e0163405 (2016).

34 Li Q and Kubota C, Effects of supplemental light quality on growth and phytochemicals of baby leaf lettuce. Environ Exp Bot 67:59-64 (2009).

35 Krumbein A and Schwarz D, Grafting: a possibility to enhance health-promoting and flavour compounds in tomato fruits of shaded plants? Sci Hortic 149:97-107 (2013).

36 Farneti B, Schouten RE, Qian T, Dieleman JA, Tijskens LMM and Woltering EJ, Greenhouse climate control affects postharvest tomato quality. Postharvest Biol Technol 86:354-361 (2013).

37 Toor RK, Savage GP and Lister CE, Seasonal variations in the antioxidant composition of greenhouse grown tomatoes. J Food Compos Anal 19:1 - 10 (2006).

38 Georgelis N, Scott JW and Baldwin EA, Relationship of tomato fruit sugar concentration with physical and chemical traits and linkage of RAPD markers. J Am Soc Hort Sci 129:839-845 (2004).

39 Young TE, Juvik JA and Sullivan JG, Accumulation of the components of total solids in ripening fruits of tomato. J Am Soc Hort Sci 118:286-292 (1993).

40 George B, Kaur C, Khurdiya DS and Kapoor HC, Antioxidants in tomato (Lycopersium esculentum) as a function of genotype. Food Chem 84:45-51 (2004).

41 Ullah I, Hanping M, Chuan Z, Javed Q and Azeem A, Optimization of irrigation and nutrient concentration based on economic returns, 
substrate salt accumulation and water use efficiency for tomato in greenhouse. Arch Agron Soil Sci 63:1748-1762 (2017)

42 Luo $\mathrm{H}$ and Li F, Tomato yield, quality and water use efficiency under different drip fertigation strategies. Sci Hortic 235:181 - 188 (2018).

43 Zhai $Y$, Yang $Q$ and Hou $M$, The effects of saline water drip irrigation on tomato yield, quality, and blossom-end rot incidence: a 3a case study in the south of China. PLoS One 10:e0142204 (2015).

44 Guil JL, Torija ME, Giménez JJ and Rodriguez I, Identification of fatty acids in edible wild plants by gas chromatography. J Chromatogr $A$ 719:229-235 (1996).
45 Floegel A, Kim DO, Chung SJ, Koo SI and Chun OK, Comparison of ABTS/DPPH assays to measure antioxidant capacity in popular antioxidant-rich US foods. J Food Compos Anal 24:1043-1048 (2011).

46 Ahmadi $L$ and Tsao $R$, The effect of greenhouse covering materials on phytochemical composition and antioxidant capacity of tomato cultivars. J Sci Food Agric 98:4427-4435 (2018).

47 Tinyane PP, Sivakumar D and Soundy P, Influence of photo-selective netting on fruit quality parameters and bioactive compounds in selected tomato cultivars. Sci Hortic 161:340-349 (2013). 